\title{
Hydrochemical Studies of the Groundwater Resources of the Middle Zone Aquifer in the Southwestern Chad Basin.
}

\author{
A.K. Yusuf ${ }^{1}$, I.B.Goni ${ }^{2}$ M. Hassan ${ }^{3}$ \\ ${ }^{1}$ Centre for Arid Zone Studies, University of Maiduguri. \\ ${ }^{2}$ Department of Geology, University of Maiduguri. \\ ${ }^{3}$ Department of Physics, University of Maiduguri.
}

\begin{abstract}
The groundwater of the Middle aquifer was collected to examine its characteristics. The chemistry of the water showed that it has SAR value of about 4.6 and EC is $667 \mathrm{Scm}^{-1}$

This makes the water suitable as fresh water and can be used for irrigation. The results were presented in Richards and Piper's diagrams for easy visualization. The water samples plots in good and permissible water class with salinity hazards of medium - high salinity groups. While the water samples plots in the same region in the piper's diagram indicating that they are hydrogeologically connected and continuous. The chemical data recognized a water type classified as sodium bicarbonate type $\left(\mathrm{Na}+\mathrm{HCO}_{3}\right)$ facies where sodium is significant in its concentration; with cation and ions in the order of $\mathrm{Na}>\mathrm{Ca}>\mathrm{K}>\mathrm{Mg}$ and $\mathrm{HCO}_{3}>\mathrm{CO}_{3}>\mathrm{Cl}>\mathrm{SO}_{4}$ for drinking water quality.
\end{abstract}

Keywords: Groundwater, Salinity hazard, Hydrogeologically, Sodium bicarbonate, Facies.

\section{Introduction}

The Chad Formation is the youngest and most prolific formation in the basin. Groundwater resources of the Nigerian sector of the Chad Basin occur in that formation. Groundwater in this deposit occurs under both confined and unconfined conditions. Three well known aquifers are demarcated in the zone by Barber and Jones (1960), as Upper, Middle and Lower aquifers. The Upper aquifer is semi-confined to confine while the Middle and Lower is in a confined condition. The Middle aquifer is the most extensive and most exploited of all the three aquifers. Because of the thick clay (in some places up to $100 \mathrm{~m}$ ), boreholes drilled to this zone yield piezometric head as high as $20 \mathrm{~m}$ above ground level ( agl ) in the 1960's. Due to the depth of occurrence and the overlying clay thickness the water in that aquifer becomes under high pressure yielding artesian wells. The lack of usage of the water for irrigation might not be unconnected with the chemistry of the water. A similar assumption was earlier made by Barber (1965) that lack of irrigation activities in the area might not be unconnected with the chemistry and temperature of the water. This lack of irrigation activities using the artesian wells water necessitated the qualitative study of the Middle zone aquifer water for both agriculture and human use.

\section{Scope Of Study}

The study area is the Middle zone aquifer of the Nigerian sector of the Chad Basin. The area falls within latitude $11^{\circ} 30^{\prime} \mathrm{N}$ and $13^{\circ} 30^{\prime} \mathrm{N}$ and longitude $12^{\circ} 00^{\prime} \mathrm{E}$ and $14^{\circ} 30^{\prime} \mathrm{E}$.

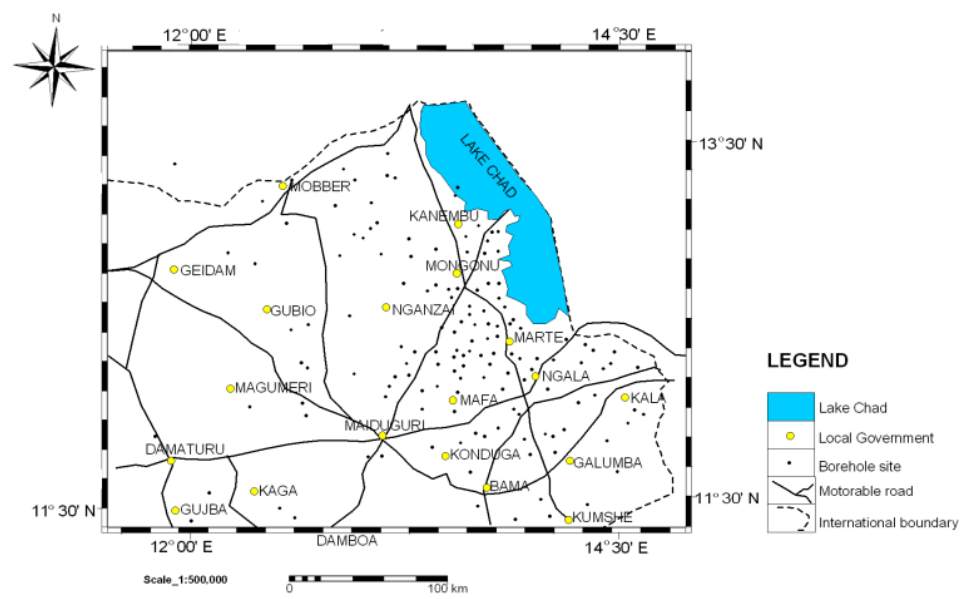

Fig.1. Map of the study area and sample locations. 


\section{Climate}

The area is a semi-arid region characterized by tropical climate with both seasonal and diurnal weather variations. The rainfall occurs mainly in the months of June- September. The temperature in the area ranges between $35^{\circ} \mathrm{C}$ to $44^{\circ} \mathrm{C}$ in March and May while in December and January the temperature range from $12^{\circ} \mathrm{C}$ to $18^{\circ} \mathrm{C}$.

\section{Soil Types}

Lake Chad Basin is a fertile area with a great agricultural potential. This potential is however limited by scarcity of water. Surface water, in streams appears seasonally for a couple of months, usually from August to November. For the rest of the year streams are dry and the only source of water is groundwater. Major crops grown in the area are cereals and legumes.

\section{Geology}

The stratigraphy and geology of the Chad Basin are well documented (Barber and Jones, 1960; Carter, Barber, Jones and Tait, 1963; Barber, 1965; Miller et al., 1968; Burke, 1976; Offodile, 1972; Adefila, 1975; Oteze and Fayose, 1988; Ndubisi, 1990; Olugboye, 1995). The Chad Formation is the youngest and last phase of deposition sequence in the stratigraphy succession of the basin. It is basically an argillaceous sequence with three well defined arenaceous horizons (Barber and Jones, 1960).

The Middle zone arenaceous horizon is the most extensive of the zones, extending to republics of Niger, Cameroun and Chad. It is overlain by variable thickness (up to $150 \mathrm{~m}$ ) of clay layer. This zone consists of sand, sandy clay and clay, with extremely variable proportion in different sections. The sand varies from fine grained to very coarse grained, with little gravel. Feldspar grains, iron ore and mica are present along with fragments of granites, but quartz grains form the bulk of the arenaceous material. The sand particles are poorly graded and usually angular to sub angular.

In few areas silica and ferruginous material, but not enough to drastically reduce the porosity and permeability of the sands cement the grains. The clays and sandy clays of the zone are usually brightly coloured. This zone is probably composed of Lake Margin deposits laid down at the mouth of the rivers which flowed into the Lake (Dar Al-Handasah, 1981). This accounts for the low degree of grading, and the vertical and lateral variability of the sediments. The sand beds are thought to occur as lenses of varying thickness and extent.

\section{Hydrogeology}

The Middle zone arenaceous horizon stores water and termed Middle zone aquifer (Barber and Jones, 1960). This aquifer is confined by a clay layer up to $100 \mathrm{~m}$ thick in some places, with pressure sufficient to cause artesian flow. Because of the heterogeneity of the aquifer materials, there is variability in hydraulic properties. Miller et al. (1968) subdivides the aquifer into six based on water yielding capability. They also give the following hydraulic parameters: Hydraulic conductivity range from $0.0000428-0.000179 \mathrm{~m} / \mathrm{sec}(90-380 \mathrm{gpd}$ per square foot); transmissivity $0.000818-0.1141 \mathrm{~m}^{2} / \mathrm{sec}(520-72,500$ gpd per foot; storage coefficient $0.000014-0.00018$. However it was observed that most of the boreholes tapping this aquifer are of very small diameter $63.5 \mathrm{~mm}(2.5 \mathrm{in})$ in relation to their depth $182-365 \mathrm{~m}(600-1200 \mathrm{ft})$, resulting in considerable head lost due to friction.

\section{Methodology}

Ninety six water samples were collected for geochemical analysis for major and minor elements in the study area. The temperature; electrical conductivity and the $\mathrm{p}^{\mathrm{H}}$ were measured by the use of water testing kit on the field. The water samples were collected from the main borehole outlet after rinsing the one litre plastic can. The samples were later taken to the Department of Geology, University of Maiduguri laboratory for the analysis. The $\mathrm{Na}$ and $\mathrm{K}$ cations were analysed using the Flame Photometer while Atomic Absorption Spectrophotometer (AAS) was used to determined $\mathrm{Mg}$ and $\mathrm{Ca}$. The titration determination was used for $\mathrm{CO}_{3}$, $\mathrm{HCO}_{3}$ and $\mathrm{Cl}$ anions while Ultra Violet Spectrophotometer was used to analyse $\mathrm{SO}_{4}$ anion.

\section{Discussions}

Despite that there is large pool of water formed by the free-flowing wells. There is no much agricultural/irrigation activities during the dry season in study area. The people in the area mostly depend on rain fed agriculture. These people are also fishermen and tend to move towards the Lake for fishing mostly during the dry season.

Lack of usage of the water for irrigation might not be unconnected with the chemistry and temperature of the water (Barber, 1965). The artesian water temperature in the area is about $40^{\circ} \mathrm{C}$ which is far above the recommended temperature for irrigation water of $14^{\circ} \mathrm{C}$ (Todd, 1980). 


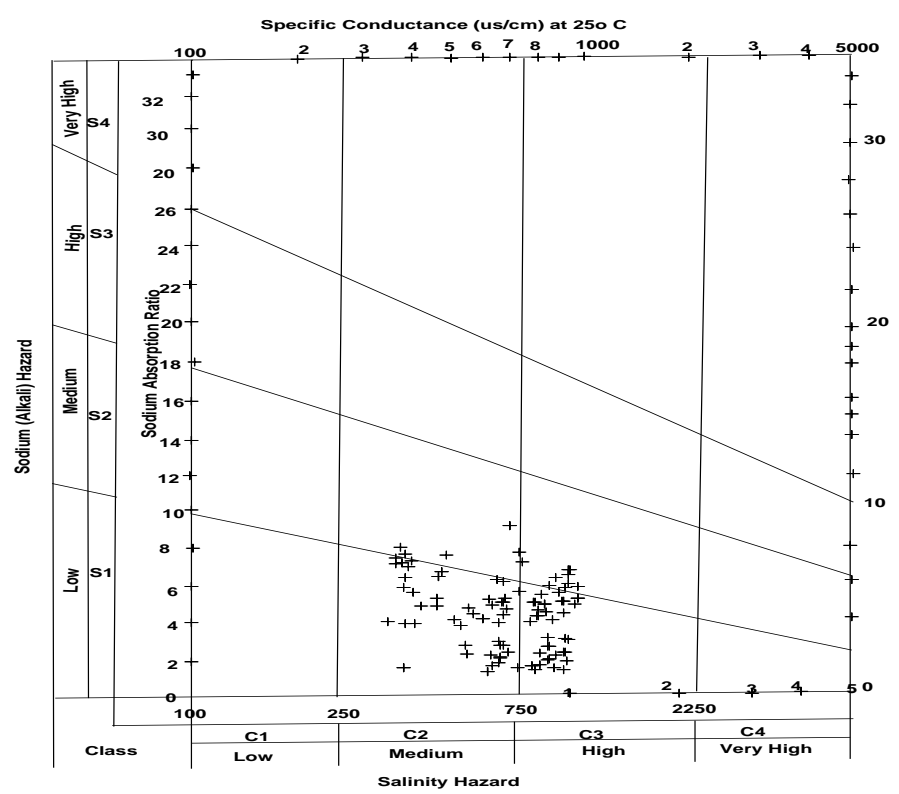

Fig.2: Graphical Classification of Irrigation water (after Richards, 1954).

The groundwater quality for irrigation from boreholes tapping the Middle Zone Aquifer was analysed for its suitability for irrigation and presented for easy understanding in a graphical Charts by Richards (1954).This Chart is based on SAR and Electrical Conductivity. The water samples from the study area fall in two dominant groups of medium and high salinity hazards of classes 2 and 3 (fig.2) which is interpreted by Wilcox (table 1) as "good and permissible grades".

The suitability of groundwater for irrigation depends on several factors, which have direct relationship with plant and soil. These include the percent sodium (percent Na) and the sodium adsorption ratio (SAR), (table 1).The percent $\mathrm{Na}$ is determined as:

$\% \mathrm{Na}=((\mathrm{Na}+\mathrm{K}) /(\mathrm{Ca}+\mathrm{Mg}+\mathrm{Na}+\mathrm{K})) 100$ $-1$

Wilcox (1948) and Todd (1980).

Where ionic concentration are expressed in milli equivalents per litre (meq/l)

In the study area, the groundwater samples have the percent sodium values ranging from 52-90 with a mean of 66.5.The major ions of $\mathrm{Na}, \mathrm{K}, \mathrm{Ca}$ and $\mathrm{Mg}$ have average values of 3, 0.46, 1.3 and $0.77 \mathrm{mg} / \mathrm{L}$ while the minor elements of $\mathrm{Cl}, \mathrm{SO}_{4}$ and $\mathrm{HCO}_{3}$ have mode values of $1.3,1.16$ and $2.42 \mathrm{mg} / \mathrm{L}$. The physical parameters of temperature and $\mathrm{P}^{\mathrm{H}}$ have $37.3^{\circ} \mathrm{C}$ and 7.14 .

Table1:Modified Wilcox quality Classification of irrigation waters (Adopted Todd 1980)

\begin{tabular}{|l|l|l|l|l|l|l|}
\hline S/No & Water Class & Grades & $\%$ Na & Electrical Us/cm & SAR & Salinity Hazard \\
\hline 1 & Class 1 & Excellent & $<20$ & 250 & $1-10$ & Low \\
\hline 2 & Class 2 & Good & $20-40$ & $250-750$ & $10-18$ & Medium \\
\hline 3 & Class 3 & Permissible & $40-60$ & $750-2000$ & $18-26$ & High \\
\hline 4 & Class 4 & Doubtful & $60-80$ & $2000-3000$ & $>26$ & Very High \\
\hline 5 & Class 5 & Unsuitable & $>80$ & $>3000$ & $>26$ & Very High \\
\hline
\end{tabular}

The risk of sodium alkalinisation is measured as a ratio, which shows the extent of the replacement of calcium and magnesium ions by sodium ions at the soil exchange sites. Richards (1954) defined this ratio, the sodium adsorption ratio (SAR) as:

$\mathrm{SAR}=\mathrm{Na}^{+} / \sqrt{ }\left(\mathrm{Ca}^{2+}+\mathrm{Mg}^{2+}\right) / 2$

Where ionic concentrations are expressed in mill equivalents per litre (meq)

A graphical classification of irrigation water based on SAR and electrical conductivity (EC) according to Richards (1954) has been prepared for the study area Fig.2.

Good irrigation water should have SAR value of less than 15 and an EC value below $750 \mathrm{uf} \mathrm{cm}^{-1}$. The average value of SAR in the study area is about 4.6 which are considered as "excellent" water class, while the

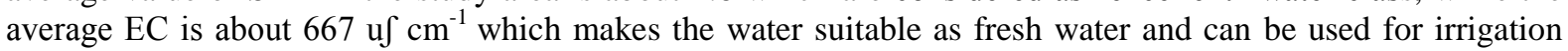
(Wilcox, 1948). Fig.2 shows that the 96 groundwater samples) plot in two major classes on this irrigation water classification diagram. Majority of the groundwater samples about $60 \%$ (58 samples) from this zone fall within the "good" water class with medium salinity hazards, while 38 samples (40\%) fall within the "permissible" class 
with high salinity group (salty) and none of the samples falls in the fresh water zone of the "excellent class". The quality of groundwater for drinking has been pointed out by numerous writers that it is largely a matter of opinion whether water is good to drink. The population of areas where low salinity waters are plentiful would probably fine quite small amounts of salts distasteful whereas dwellers in more arid countries have much more tolerant limits. Thus, rigid standards of chemical quality cannot be established except for definitely toxic substances. Dixey (1931,) remarks that in England and the Eastern united State, $570 \mathrm{ppm}$ was regarded as the extreme limit of salinity. Later workers, influenced by data from dessert regions, regard concentrations as high as 2,500 ppm of soluble salts as permissible. In parts New Mexico and California water with 4,000 ppm is used for drinking and water with $2000 \mathrm{ppm}$ is regarded as good. Bearing in mind the quality of the water available to the people of north - eastern Borno and Dikwa prior to the tapping to the artesian supplies, it is not surprising that there been relatively few complaints about the portability of the pressure water.

The average results of the major and minor elements concentration are presented in (Appendix 1).All the groundwater samples of the Middle aquifer tend to plot in the same region, this indicate that they are hydrogeologically connected and continuous .Detailed analysis of the major ions indicates that alkali metal $(\mathrm{Na}+\mathrm{K})$ and bicarbonate are dominant in majority of the groundwater only differing in relative percentage. The major cations $\mathrm{Ca}, \mathrm{Mg}$, and the alkali metal $(\mathrm{Na}+\mathrm{K})$ constitute only about $5 \%$, $2 \%$ and $19 \%$ respectively. While the anions of $\mathrm{CO}_{3}+\mathrm{HCO}_{3}, \mathrm{SO}_{4}$ and $\mathrm{Cl}$ constitute $51 \%, 11 \%$ and $12 \%$ respectively. The major cations of $\mathrm{Na}, \mathrm{K}, \mathrm{Ca}$ and $\mathrm{Mg}$ have a mean value of $98 \mathrm{mg} / \mathrm{L}, 20 \mathrm{mg} / \mathrm{L}, 31 \mathrm{mg} / \mathrm{L}$ and $12 \mathrm{mg} / \mathrm{L}$ respectively. The above concentrations are within WHO (1984) standards for drinking water. Furthermore, major anions of $\mathrm{CO}_{3}, \mathrm{HCO}_{3}, \mathrm{SO}_{4}$ and $\mathrm{Cl}$ have an average value of $87 \mathrm{mg} / \mathrm{L}, 224 \mathrm{mg} / \mathrm{L}, 64$ $\mathrm{mg} / \mathrm{L}$ and $71 \mathrm{mg} / \mathrm{L}$ respectively. These concentrations are all within the WHO (1984) requirement for portable water. It revealed that the cations plot in the region of dominant $\mathrm{Na}$ cations; while the anions plots towards where the bicarbonate is dominant hence the water from Middle zone aquifer of the Nigerian sector of the Chad Basin is classified as sodium bicarbonate type $\left(\mathrm{Na}+\mathrm{HCO}_{3}\right)$.

The results of the chemical analysis are presented in a piper diagram (Fig.3) in order to facilitate interpretation by visual inspection. The cation and anion in the groundwater of the Middle zone aquifer of the Chad Formation in the Nigerian sector of the Chad Basin are in the order: $\mathrm{Na}>\mathrm{Ca}>\mathrm{K}>\mathrm{Mg}$ and $\mathrm{HCO}_{3}>\mathrm{CO}_{3}$ $>\mathrm{Cl}>\mathrm{SO}_{4}$ respectively.

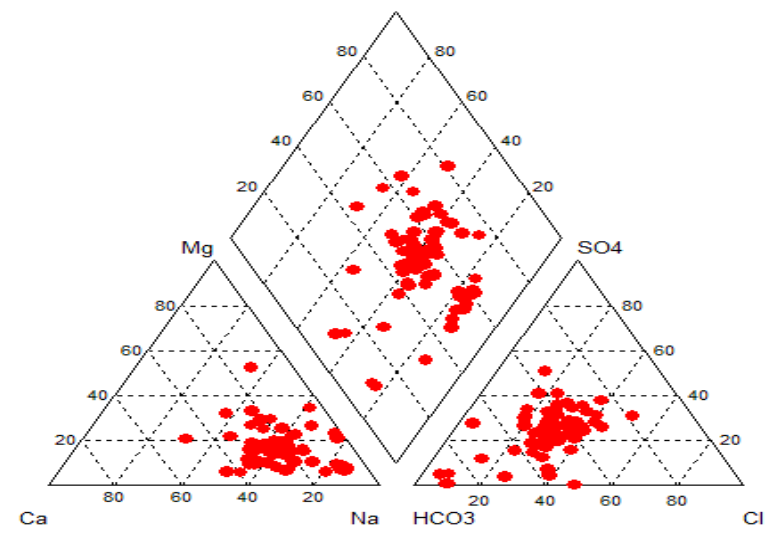

Fig.3: Piper's Diagram for the water analysis of the Middle zone aquifer of the Nigerian sector of the

Chad Basin.

\section{Conclusion}

The groundwater of the Middle aquifer has SAR value of about 4.6 and EC is $667 \mathrm{Scm}^{-1}$

This makes the water suitable as fresh water and can be used for irrigation. The water samples plots in good and permissible water class with salinity hazards of medium - high salinity groups. These two classes of water can be used for irrigation. While the water quality is classified as Sodium Bicarbonate type $\left(\mathrm{Na}+\mathrm{HCO}_{3}\right)$ facies and is within the $\mathrm{WHO}$ requirement for drinking water.

\section{Acknowledgement}

The authors are greatly indebted to the University of Maiduguri for financing the research. Water quality analysis of the samples was carried out by Mohammed Isiaka of the Department of Geology, University of Maiduguri. The authors also thank the anonymous reviewers for their suggestion and comments on the paper. 


\section{References}

[1]. Adefila, S.F. (1975): Decline in the Pressure of the Middle Aquifer of the Chad Formation in Parts of the South Eastern Niger and North Eastern Nigeria. J. Mining and Geology, 12: 23-26.

[2]. Barbers, W. (1965): Pressure Water in the Chad Formation of Bornu and Dikwa Emirate, Northeastern Nigeria. Geological Survey of Nigeria Bulletin No. 35,138p.

[3]. Barber, (1965) W. and Jones, D.G. (1960):The Geology and Hydrology of Maiduguri, Bornu Province (Unpublished Records) Geological Survey of Nigeria.1958,P1-20

[4]. Burke,K.C.,(1976): The Chad Basin; an active intra- continental basin. Tectonophysics, 36. Pp 197 -206.

[5]. Carter , J.D., Barber, W., Tait, E.A., Jones , D. G. (1963) : The Geology of Parts of damawa, Bauchi and Borno Provinces, Northeastern Nigeria: Bulletin of Geological Survey of Nigeria, No.30.

[6]. Dar Al-Handasah. (1983): Maidugrui Water Supply; Feasibility Study Final Report. Dar Al-Handasah (Shair and Partners): Maiduguri.

[7]. Miller, R.E., Johnson, R.H., Olowu J.A.I. and Uzeoma J.U., (1968): Groundwater Hydrology of the Chad Basin in Borno and Dikwa Emirates; North-Eastern Nigeria with Special Emphases on the Flows Life of the Artesian System. Hydrology of Africa and the Mediterranean Regions.USGS Water Supply Report, 1757 - 1, 48p.

[8]. Ndubisi, O.L., (1990): Managing GroundwaterbResources of the Lake Chad Basin in Nigeria.

Proc.Nat.Hydrol.Symp.Maiduguri.Pp $429-436$.

[9]. Offodile, M.E. (1972): Groundwater Level Fluctuation in the East Chad Basin of Nigeria.

[10]. Min. Geol. Vol. 7. No. 1\&2: 19-34.

[11]. Olugboye, M.O., (1995): Groundwater Monitoring Network as an aid to averting some Ecological Disaster, the Case for Chad Basin Area. Water Resources, Vol. 6 No.1\&2: 57-60.

[12]. Oteze, G.E. and Fayose, S.A. (1988): Regional Development in the Hydrogeology of Chad Basin. Water Resources Vol. 1 No. 9-29.

[13]. Piper, A.M. (1944).A graphic procedure in geochemical interpretation of water analysis: Trans, Amer. Geophysical Union, Union, Vol. 25, pp. $914-928$.

[14]. Richards, L. A. (1954). Diagnosis and improvement of saline and alkali soils. U.S. Dept. of Agric. Handbook No.50. U.S. Govt. Printing Office, Washington D. C., 160p.

[15]. Todd, D.K.(1980):Groundwater Hydrology, $2^{\text {nd }}$ ed. John Wiley and Son Inc.535p.

[16]. Wilcox, L.V. (1948): The quality of water for irrigation use. U. S. Dept. of Agricture Tech. Bull. 962 , pp 1 - 40.

[17]. World Health Organisation (1984): Guidelines for Drinking Water Quality Vol.1.

[18]. Recommendations, WHO, Geneva, Switzerland. Pp139. $\mathrm{mg} / \mathrm{L})$

Appendix 1: Middle Zone Aquifer Water Analysis in the Nigerian Sector of the Chad Basin (in

\begin{tabular}{|c|c|c|c|c|c|c|c|c|c|c|c|c|c|}
\hline S/No & Location & L.G.A. & $\mathrm{PH}$ & ToC & $\mathrm{EC}$ & $\mathrm{Na}$ & $\mathrm{Ca}$ & $\mathrm{K}$ & $\mathrm{Mg}$ & $\mathrm{Cl}$ & SO4 & $\mathrm{CO} 3$ & $\mathrm{HCO} 3$ \\
\hline 1 & Damboa & Damboa & 6.84 & 31.6 & 670 & 52.6 & 1.32 & 2.2 & 8.6 & 10 & 1.2 & 22 & 161.4 \\
\hline 2 & Dalwa & Konduga & 6.82 & 32 & 664 & 70.61 & 1.9 & 3.4 & 10.3 & 12 & 1.33 & 33 & 183.1 \\
\hline 3 & Airport & Maiduguri & 7.21 & 34.4 & 552 & 49.36 & 14.88 & 8.55 & 5.61 & 46 & 7.39 & 95.3 & 115.9 \\
\hline 4 & Chobbal & Konduga & 7.22 & 34.5 & 585 & 48.4 & 16.71 & 9.6 & 7.4 & 48.4 & 12.8 & 92.6 & 125 \\
\hline 5 & Tungushe & Nganzai & 6.95 & 35 & 647 & 35.6 & 48.49 & 27.7 & 12.62 & 58 & 30.18 & 88.6 & 167.3 \\
\hline 6 & Kurnowa & Nganzai & 6.42 & 36 & 612 & 73.51 & 19.99 & 14.8 & 11 & 72 & 38.7 & 138.1 & 138.1 \\
\hline 7 & Gajiganna & Nganzai & 7.2 & 38.2 & 680 & 106 & 78.54 & 7.92 & 6.88 & 82 & 76 & 122 & 245.3 \\
\hline 8 & Gajiram & Nganzai & 6.88 & 37.4 & 720 & 103 & 14.4 & 13 & 5.88 & 84.6 & 75 & 122 & 248 \\
\hline 9 & Badu & Nganzai & 6.5 & 38.8 & 740 & 116.4 & 35.6 & 21.4 & 7.3 & 98.2 & 94.4 & 137.8 & 258 \\
\hline 10 & Gudumbali & Guzamala & 7.2 & 37.6 & 746 & 122.3 & 39.6 & 28.2 & 6.4 & 87.8 & 90 & 141.6 & 255.3 \\
\hline 11 & Garere & Mobbar & 6.54 & 38.6 & 812 & 235.5 & 36.4 & 32.6 & 11.7 & 96.3 & 101.2 & 156.4 & 276.6 \\
\hline 12 & Arege & Mobbar & 6.8 & 38.4 & 952 & 268 & 43.2 & 14.5 & 13.4 & 105.8 & 106.2 & 154.3 & 282.2 \\
\hline 13 & Maiduguri & Maiduguri & 6.9 & 35.6 & 414 & 52.71 & 13.25 & 15 & 6.44 & 18 & 19.9 & 77.2 & 156.3 \\
\hline 14 & Mbutta & Mafa & 6.9 & 39.1 & 820 & 65.9 & 45.06 & 25.5 & 17.51 & 60 & 12.39 & 130.7 & 280.7 \\
\hline 15 & Kesa Nga & Mafa & 6.8 & 38.6 & 846 & 69.55 & 23.43 & 26.3 & 9.64 & 62 & 51.4 & 90.5 & 100.2 \\
\hline 16 & Masu & Mafa & 6.8 & 39.2 & 856 & 71.3 & 32.52 & 28.3 & 11.24 & 66 & 55.6 & 96.4 & 105.4 \\
\hline 17 & Ngurno & Monguno & 7.3 & 39.4 & 415 & 74.2 & 34.6 & 27.55 & 12.6 & 68 & 59.7 & 103.6 & 122.6 \\
\hline 18 & Kauwa $\mathrm{Ob}$ & Kukawa & 7.3 & 30.1 & 352 & 83.14 & 39.6 & 25.25 & 13.99 & 69 & 82.59 & 228 & 170.86 \\
\hline 19 & Baga & Kukawa & 7.28 & 38.2 & 386 & 91.96 & 39.8 & 0.65 & 16.29 & 73 & 106.46 & 284 & 317.3 \\
\hline 20 & Auno & Konduga & 7.2 & 34.2 & 682 & 75.6 & 15.67 & 10.6 & 12.26 & 66.8 & 68.2 & 52.4 & 192.8 \\
\hline 21 & Gabchari & Kaga & 7.1 & 33.8 & 680 & 76.3 & 28.38 & 11.25 & 5.32 & 72 & 71.4 & 78.5 & 193.4 \\
\hline 22 & Kingowa & Magumeri & 7 & 34.1 & 688 & 88.4 & 48.49 & 11.7 & 7.62 & 78 & 76.18 & 88.6 & 197.3 \\
\hline 23 & G.Bukarti & Magumeri & 7.2 & 35.5 & 692 & 92.1 & 46.8 & 12.6 & 10.4 & 83.4 & 79.6 & 97.4 & 208.6 \\
\hline 24 & Magumeri & Magumeri & 6.92 & 35.8 & 682 & 94.8 & 51.2 & 12 & 9.8 & 81.6 & 76.2 & 95.3 & 206.8 \\
\hline 25 & Kabulele & Gubio & 7.2 & 36.2 & 890 & 102.2 & 51.8 & 11.8 & 8.8 & 76.9 & 77.2 & 102.4 & 216.6 \\
\hline 26 & Kwa & Gubio & 7.2 & 39.2 & 892 & 114.6 & 53.1 & 12.2 & 10.6 & 80.1 & 79.4 & 98.6 & 210 \\
\hline 27 & Chingowa & Gubio & 7.3 & 37.2 & 840 & 106.4 & 53 & 12.8 & 10.9 & 81.2 & 81.6 & 99.3 & 224.3 \\
\hline 28 & Gazabure & Gubio & 6.9 & 39 & 827 & 125.6 & 51.9 & 13.4 & 10.9 & 80.3 & 84.9 & 97.7 & 231.4 \\
\hline 29 & Majiri & Gubio & 6.8 & 38.8 & 842 & 150.3 & 52.3 & 12.6 & 11 & 79.3 & 85.2 & 102.3 & 232.2 \\
\hline 30 & Tamsuguwa & Mobbar & 6.46 & 39.8 & 862 & 162.4 & 52.8 & 13.5 & 11.1 & 79.6 & 86.6 & 99.8 & 233.4 \\
\hline 31 & Gashagar & Mobbar & 6.33 & 40 & 844 & 168.6 & 52.7 & 13.4 & 10.9 & 80.6 & 85.4 & 104.2 & 233.6 \\
\hline 32 & Damaturu & Damaturu & 6.7 & 31.4 & 506 & 21.9 & 12.84 & 18.7 & 3.86 & 5.6 & 4.9 & 98.4 & 102.6 \\
\hline 33 & Kukaretta & Damaturu & 6.8 & 31.6 & 508 & 27.2 & 14 & 39.62 & 4.37 & 6 & 7.27 & 117.2 & 188.7 \\
\hline 34 & Ngamdu & Kaga & 6.84 & 32 & 546 & 70.5 & 27.17 & 12.6 & 9.5 & 46 & 57.89 & 69.6 & 164.8 \\
\hline 35 & Benisheik & Kaga & 7.2 & 34.8 & 592 & 71.8 & 29.4 & 10.34 & 10.61 & 48.2 & 46.24 & 57.2 & 171.4 \\
\hline 36 & Mainok & Kaga & 6.74 & 33 & 688 & 72.44 & 23.8 & 12.8 & 11.7 & 62 & 44.75 & 55.8 & 174.5 \\
\hline 37 & Kesawa & Magumeri & 6.8 & 33.8 & 692 & 73.2 & 22.6 & 11.4 & 10.8 & 64.7 & 66.4 & 50 & 183.2 \\
\hline 38 & Muna & Maiduguri & 7.1 & 36.2 & 826 & 74.8 & 18.92 & 13.62 & 17.4 & 56.4 & 48.2 & 83.6 & 189.4 \\
\hline 39 & Shuari & Mafa & 6.77 & 35 & 954 & 112.5 & 22.33 & 14.31 & 21.45 & 63 & 57.37 & 75.4 & 292.9 \\
\hline 40 & Mafa & Mafa & 6.93 & 36.5 & 966 & 106.8 & 31.89 & 29.7 & 14.6 & 128 & 71.28 & 106.8 & 231.9 \\
\hline
\end{tabular}




\begin{tabular}{|c|c|c|c|c|c|c|c|c|c|c|c|c|c|}
\hline 41 & Majigetti & Dikwa & 6.96 & 38.2 & 974 & 126.4 & 36.7 & 32.7 & 15.8 & 124.8 & 93.6 & 62.8 & 348 \\
\hline 42 & M. Majia & $\begin{array}{l}\text { Dikwa } \\
\text { Kala }\end{array}$ & 6.6 & 38.8 & 980 & 124.8 & 32.64 & 38.42 & 18.4 & 129.9 & 104.8 & 37.6 & 352.8 \\
\hline 43 & Koma & Balge & 7 & 39 & 980 & 188.3 & 36.8 & 41.3 & 21.8 & 153.8 & 120 & 18.7 & 362.8 \\
\hline 44 & Konduga & Konduga & 7.17 & 32.8 & 678 & 86.4 & 18.9 & 33.8 & 16.4 & 68.3 & 71.8 & 34 & 224.8 \\
\hline 45 & Kadari & Konduga & 7.26 & 32.9 & 688 & 94.2 & 31.4 & 34.6 & 17.2 & 112.8 & 106.3 & 36.1 & 268.8 \\
\hline 46 & Kaza & Dikwa & 7.1 & 38.2 & 962 & 127.3 & 36.4 & 42.6 & 21.3 & 127.6 & 116.4 & 41.2 & 371.4 \\
\hline 47 & Muktu & Dikwa & 7 & 38.6 & 966 & 134.1 & 40.8 & 46.5 & 19.4 & 126.4 & 121.3 & 42.3 & 386.5 \\
\hline 48 & Dogamashe & $\begin{array}{l}\text { Dikwa } \\
\text { Kala }\end{array}$ & 7.3 & 38 & 938 & 132.8 & 44.3 & 47.2 & 19.2 & 131.8 & 143.6 & 42.1 & 388.2 \\
\hline 49 & Ran & Balge & 7.3 & 39 & 975 & 154.7 & 56.3 & 48.3 & 18.8 & 152.4 & 144.4 & 44.3 & 391.6 \\
\hline 50 & Lawanti & Kukawa & 7.35 & 40.3 & 382 & 5143 & 3.85 & 15.34 & 2.897 & 28 & 36.79 & 132 & 207.97 \\
\hline 51 & B. Lawanti & Kukawa & 7.27 & 39.1 & 369 & 50.37 & 4.62 & 17.66 & 3.046 & 30 & 43.12 & 36 & 244.1 \\
\hline 52 & Sidjin & Kukawa & 8.46 & 43 & 398 & 22.73 & 7.352 & 27.99 & 18.28 & 30 & 78.22 & 60 & 54.22 \\
\hline 53 & Gwange & Kukawa & 8.72 & 42.1 & 576 & 51.54 & 10.2 & 18.84 & 6.377 & 50 & 73.2 & 151.2 & 292.89 \\
\hline 54 & Mile 1 & Kukawa & 8.49 & 43.7 & 360 & 49.76 & 3.78 & 14.4 & 2.083 & 32 & 37.93 & 84 & 219.7 \\
\hline 55 & C. Kauwa & Kukawa & 8.75 & 42.9 & 700 & 52.47 & 11.289 & 18.38 & 6.674 & 38 & 72.25 & 132 & 175.54 \\
\hline 56 & Budumari & Kukawa & 8.7 & 42.5 & 1040 & 51.96 & 19.83 & 25.25 & 16.29 & 30 & 106.46 & 84 & 317.3 \\
\hline 57 & Kauwa L & Kukawa & 8.61 & 38.8 & 477 & 53.14 & 9.6 & 17.55 & 3.998 & 46 & 82.59 & 228 & 170.86 \\
\hline 58 & Bundur & Kukawa & 7.3 & 41.1 & 477 & 51.75 & 4.57 & 25.45 & 2.999 & 32 & 56.32 & 132 & 268.5 \\
\hline 59 & Madari & Kukawa & 7.3 & 40.9 & 436 & 50.58 & 3.75 & 11.84 & 2.623 & 26 & 49.38 & 156 & 244.1 \\
\hline 60 & Kekeno & Kukawa & 7.34 & 39.1 & 420 & 50.82 & 4.33 & 9.59 & 2.612 & 26 & 44.52 & 156 & 268.5 \\
\hline 61 & Yoyo & Kukawa & 7.38 & 39.2 & 378 & 50.54 & 3.87 & 9.489 & 2.386 & 22 & 38.56 & 119.99 & 219.7 \\
\hline 62 & MN- 1 & Monguno & 7.31 & 39.1 & 427 & 51.22 & 7.4 & 9.43 & 2.067 & 24 & 38.28 & 84 & 268.5 \\
\hline 63 & MN- 2 & Monguno & 7.26 & 38.8 & 408 & 50.09 & 4.2 & 9.43 & 2.255 & 18 & 39.59 & 119.99 & 195.26 \\
\hline 64 & $\mathrm{MN}-4$ & Monguno & 8.62 & 38.4 & 415 & 50.76 & 3.75 & 9.362 & 2.139 & 26 & 38.04 & 108 & 317.3 \\
\hline 65 & $\mathrm{MN}-6$ & Monguno & 7.28 & 38.2 & 386 & 51.51 & 3.78 & 10.12 & 2.259 & 28 & 34.3 & 228 & 170.86 \\
\hline 66 & $\mathrm{MN}-5$ & Monguno & 7.35 & 40.5 & 401 & 51.26 & 3.92 & 9.72 & 2.459 & 28 & 43.34 & 228 & 170.86 \\
\hline 67 & $\mathrm{MN}-3$ & Kukawa & 7.29 & 42.6 & 422 & 51.64 & 3.42 & 10.21 & 2.413 & 4 & 37.37 & 84 & 317.3 \\
\hline 68 & Veternary & Kukawa & 7.32 & 38.3 & 486 & 51.15 & 3.31 & 11.14 & 2.232 & 20 & 35.24 & 108 & 219.7 \\
\hline 69 & Ali Banya & Marte & 6.73 & 40.1 & 979 & 14.3 & 10.18 & 15.66 & 6.523 & 10 & 73.22 & 204 & 341.7 \\
\hline 70 & Ala 1 & Marte & 6.66 & 38 & 954 & 18.75 & 8.098 & 15.05 & 7.42 & 24 & 42 & 168 & 366.12 \\
\hline 71 & Ala 2 & Marte & 6.87 & 35.7 & 950 & 18.84 & 5.816 & 17.13 & 5.676 & 66 & 78.27 & 156 & 414.9 \\
\hline 72 & Kaje & Marte & 6.67 & 39.8 & 900 & 19.06 & 10.78 & 16.43 & 5.697 & 32 & 62 & 228 & 366.12 \\
\hline 73 & Garadai & Marte & 6.9 & 34.4 & 877 & 19.32 & 7.324 & 14.79 & 4.952 & 62 & 62.24 & 204 & 317.3 \\
\hline 74 & N. Marte & Marte & 7.82 & 41.6 & 674 & 18.75 & 8.612 & 15.765 & 6.025 & 28 & 59.4 & 119.99 & 305.1 \\
\hline 75 & Bul. Biafra & Dikwa & 6.63 & 35.6 & 851 & 19.08 & 6.959 & 14.77 & 8.265 & 28 & 25.97 & 156 & 341.7 \\
\hline 76 & Gajibo & Dikwa & 6.68 & 36.2 & 965 & 18.78 & 10.95 & 16.72 & 8.015 & 38 & 32.24 & 108 & 414.9 \\
\hline 77 & Logomani 1 & Ngala & 6.91 & 36.6 & 848 & 19.05 & 8.51 & 15.53 & 5.546 & 42 & 28.44 & 228 & 366.12 \\
\hline 78 & Logomani 2 & Ngala & 6.78 & 37.7 & 873 & 19.1 & 8.454 & 15.57 & 5.854 & 44.02 & 46.22 & 204 & 183.1 \\
\hline 79 & Ngala & Ngala & 7.95 & 37.5 & 698 & 19.16 & 10.923 & 14.86 & 6.748 & 42 & 10.762 & 136.8 & 266 \\
\hline 80 & Kiyuba & Ngala & 6.99 & 40.7 & 715 & 18.65 & 4.88 & 10.89 & 3.968 & 26 & 30 & 156 & 414.9 \\
\hline 81 & S. Dikwa & Dikwa & 6.95 & 35.9 & 810 & 18.21 & 10.73 & 11.59 & 6.333 & 42.55 & 27.7 & 108 & 366.16 \\
\hline 82 & Ad. Dikwa & Dikwa & 6.78 & 34.1 & 810 & 18.51 & 5.262 & 12.36 & 6.688 & 46.22 & 6.59 & 168 & 317.3 \\
\hline 83 & Rabiri & Dikwa & 6.54 & 39.5 & 752 & 18.84 & 7.286 & 17.19 & 6.617 & 48.42 & 14.51 & 84 & 366.16 \\
\hline 84 & Bama & Bama & 7.1 & 31.6 & 246 & 62.8 & 16.3 & 6.2 & 8.9 & 12.4 & 46.3 & 38.4 & 170.6 \\
\hline 85 & Bulonguwa & Dikwa & 6.8 & 37.5 & 292 & 84.6 & 17.6 & 10.4 & 12.6 & 18.2 & 53.4 & 62.4 & 185.6 \\
\hline 86 & Yedi & Marte & 7.9 & 38.1 & 589 & 47.4 & 17.8 & 13.9 & 11.2 & 39 & 61.3 & 118.6 & 110.8 \\
\hline 87 & Waramari & Bama & 7.2 & 30.8 & 248 & 63.2 & 5.9 & 6.2 & 6 & 11 & 45.9 & 39.8 & 148 \\
\hline 88 & Jurom & Mafa & 7.1 & 35.6 & 321 & 73.4 & 6.4 & 10.4 & 8 & 23 & 72.8 & 110.8 & 136 \\
\hline 89 & $\begin{array}{l}\text { Kinjimeram } \\
\text { Karaga }\end{array}$ & Mafa & 7.6 & 37.2 & 564 & 98.3 & 13.1 & 12.2 & 8.7 & 48.4 & 76.3 & 128.4 & 178 \\
\hline 90 & Waru & Kaga & 6.72 & 34 & 588 & 41.6 & 17.5 & 11.8 & 9.2 & 23.8 & 61.3 & 89.4 & 168.6 \\
\hline 91 & Wamiri & Kukawa & 7.1 & 38.6 & 388 & 64.3 & 18.4 & 16.6 & 12.8 & 44.2 & 78.3 & 125 & 170.9 \\
\hline 92 & Goniri & Gujba & 6.4 & 31 & 212 & 28.4 & 8.9 & 7.3 & 5.8 & 3.7 & 42.3 & 56.2 & 122.6 \\
\hline 93 & Chira Chira & Magumeri & 7 & 38.4 & 346 & 43.6 & 16.9 & 13.8 & 12.4 & 41.8 & 66.6 & 122 & 172.3 \\
\hline 94 & Bindundul & Gubio & 7.2 & 36.5 & 324 & 41.2 & 2.4 & 6.8 & 1.4 & 15.2 & 22.4 & 58.9 & 224.6 \\
\hline 95 & Chawa & Gubio & 7.3 & 38.7 & 851 & 84.8 & 48.2 & 31.6 & 18.9 & 68.6 & 82 & 96.4 & 343.5 \\
\hline \multirow[t]{2}{*}{96} & Damasak & Mobbar & 7.5 & 39.6 & 1256 & 132.4 & 74.2 & 38.9 & 22.2 & 98.4 & 92.6 & 161.3 & 384.2 \\
\hline & Average & & 7.14 & 37.3 & 667 & 126.335 & 22.71 & 17.7123 & 9.4 & 55.52 & 60.29 & 110.117 & 240.528 \\
\hline
\end{tabular}

